The LAW OF PeOPLeS by John Rawls (Cambridge: Harvard University Press, 1999)

\title{
I. INTRODUCTION'
}

We think we know what we are talking about when we discuss justice: Do people have rights? What constraints does justice place on the distribution of material well-being? Of course we have many candidates for answers: utilitarianism in one of its variants and rights-based answers of various sorts. Typically, though, we do not question the domain over which these principles of justice apply. ${ }^{2}$ In particular, my sense is that it takes some effort to displace the sense that the domain of justice is the territorially defined nation. ${ }^{3}$ We invoke liberal principles of justice within the nation, and seek to advance the national interest outside it. On reflection, this default assumption about the domain of justice is odd. After all, philosophers' arguments for principles of justice are based on the characteristics of persons - that they are rational, that they are self-interested, and the like. These characteristics are shared by all members of the human species, no matter where located. So, it might seem, the domain of the philosophers' principles of justice is everyone everywhere, without distinction based on place.

John Rawls' latest work defends the default assumption, albeit in his distinctive way. ${ }^{4}$ $\mathrm{He}$ articulates the principles of justice that would regulate what he calls peoples rather than persons. ${ }^{5}$ Peoples differ from persons, according to Rawls, because they are "united by what Mill called 'common sympathies."'6 Rawls develops a Law of Peoples that provides the principles to guide two classes of peoples: reasonable liberal peoples and decent (nonliberal) peoples. ${ }^{7} \mathrm{He}$ offers his enterprise as an effort to describe a "realistic utopia," using the thought of Jean-Jacques Rousseau that our political principles should "tak[e] men as they are and laws as they might be."

$1 \quad$ My thinking about Rawls' book was aided by reading a draft of a review-essay by Charles Beitz (see C.R. Beitz, "Rawls' Law of Peoples" (2000) 110 Ethics 669. This essay benefitted from comments by Louis $M$. Seidman on an earlier draft. Animal-rights proponents do question the usual limitation of the domain of justice to members of the human species. See e.g. P. Singer, Animal Liberation, rev. ed. (New York: Avon Books, 1991). Feminist scholars have attempted to identify the principles of justice within the family. See e.g. S.M. Okin, Justice, Gender, and the Family (New York: Basic Books, 1989). My sense is that here too it has taken, and still takes, some effort to persuade most (or perhaps only most male) readers that there are principles of justice that regulate relations within families.

$4 \quad$ J. Rawls, The Law of Peoples (Cambridge: Harvard University Press, 1999).

s Or, more precisely, peoples with certain characteristics, and specifically not all the nations of the earth.

- Supra note 4 at 23. As we will see, Rawls places other conditions on the peoples to whom the Law of Peoples applies, but I believe that the "common sympathies" characteristic is what distinguishes peoples from persons. He identifies three other types of peoples: outlaw states, societies burdened by unfavourable conditions, and benevolent absolutisms (ibid. at 4).

Ibid. at 13, quoting from J.J. Rousseau, The Social Contract and Discourses, trans. G.D.H. Cole (New York: E.P. Dent and Sons, 1950). 
After outlining Rawls' methodology and his conclusions, ${ }^{9}$ this essay raises two questions about Rawls' arguments. First, does Rawls successfully explain why we should be concerned with a Law of Peoples rather than a law of persons no matter where located? Here, I believe, Rawls provides the outlines for answering yes, but he dismisses too readily the ground for a negative answer. Second, does he describe a realistic utopia? Here I am more skeptical. The difficulty is that he asks us to take people "as they are"10 (or in another formulation, "you and I, here and now"'), but provides us with little reason to think that people as they are, at least people "here and now" organized as peoples, would give the answers he offers.

\section{The STRUCTURE OF THE ARgUment}

Rawls develops his argument in a way that should by now be familiar, but which is, I think, often misunderstood by legal academics. The basic idea is to posit certain characteristics of the people about whom one is interested ${ }^{12}$ specify certain principles, and then show that people with those characteristics would choose (or accept) those principles because the principles advance the interests they have.

In developing a Law of Peoples, Rawls proceeds in two steps. First, he asks what principles a liberal people would accept, knowing that they live in a world with other liberal peoples. A liberal people has adopted liberal principles of justice for itself. Why would those same principles not govern their relation with other liberal peoples? Or, to put it another way, why should we refrain from seeing the world of liberal peoples as a unitary liberal society, regulated by a single set of liberal principles? As Rawls stressed in Political Liberalism, the answer is reasonable pluralism. All liberal peoples will accept liberal principles, but what they accept will be principles specified at a fairly abstract level, and much that each people values will rest on what Rawls calls "comprehensive conceptions of the good."13 Two liberal peoples might accept Rawls' difference principle for distributive justice, for example, but they might differ over the policies that the principle entails in any given set of circumstances. Important aspects of each people's organized lives will be governed by comprehensive views that each knows the other

y Here, I focus on the first and larger part of The Law of Peoples. The book contains a second part, which reprints Rawls' mature reflections on the "idea of public reason" (initially published in J. Rawls, "The Idea of Public Reason Revisited" (1997) 64 U. Chi. L. Rev. 765), which plays a large part in his analysis in Political Liberalism (New York: Columbia University Press, 1993). I have dealt with the idea of public reason elsewhere, and have nothing to add to my earlier discussion. See M.V. Tushnet, Taking the Constitution A way From the Courts (Princeton, NJ: Princeton University Press, 1999) c. 4.

Jbid. at 30.

In Rawls' terms, the specification is modeled by the so-called original position. But it is important to understand that Rawls does not make any claims about what actual people would choose or accept. Actual people may lack the specified characteristics or may have interests other than those that flow from them.

Supra note 4 at 34. 
reasonably rejects. The Law of (liberal) Peoples will be thinner than the law in any particular liberal society. ${ }^{14}$

Liberal peoples have fundamental interests in political independence, a free culture and civil liberties, the security of their society, and the integrity of their territory. ${ }^{15}$ Rawls lists eight "familiar and traditional principles of justice among free and democratic peoples."16 These principles largely track the principles of international law, although they do not include some traditional international legal principles, nor do they include a duty of assistance not yet recognized by international law. And Rawls notes that a Law of Peoples for liberal peoples need not include the rule that societies must respect human rights, because liberal peoples do so already. ${ }^{17}$ It is precisely because these principles are so unremarkable that they can be accepted by liberal peoples to regulate their relations among themselves.

The second step in identifying the principles of the Law of Peoples extends it to an international system containing liberal peoples and decent nonliberal ones. Rawls defines decent nonliberal peoples as those "whose basic institutions meet certain specified conditions of political right and justice (including the right of citizens to play a substantial role, say through associations and groups, in making political decisions) and lead their citizens to honour a reasonably just law for the Society of Peoples." ${ }^{.18}$ Rawls then argues that decent nonliberal peoples would accept the principles of the Law of Peoples because those principles advance their fundamental interests just as the principles advance the fundamental interests of liberal peoples. Obviously, liberal peoples and decent nonliberal ones have a fundamental interest in freedom and independence. Both groups will undertake a duty of non-intervention: liberal peoples will do so with respect to other liberal peoples because the others are liberals, and with respect to decent nonliberal ones because they are decent; decent nonliberal peoples will do so because they are decent, which Rawls has defined to include the requirement that they honour reasonably just principles of the Law of Peoples. The general construction proceeds along the same lines:

I wonder, though, whether liberal societies differ dramatically in the "thickness" of the set of human rights they respect. Rawls' presentation suggests that all liberal peoples will in fact respect a reasonably thick set.

Supra note 4 at 34.

The principles are:

1. Peoples are free and independent, and their freedom and independence are to be respected by other peoples.

2. Peoples are to observe treaties and undertakings.

3. Peoples are equal and are parties to the agreements that bind them.

4. Peoples are to observe a duty of non-intervention.

5. Peoples have the right of self-defense but no right to instigate wars for reasons other than self-defense.

6. Peoples are to honor human rights.

7. Peoples are to observe certain specified restrictions in the conduct of war.

8. Peoples have a duty to assist other peoples living under unfavourable conditions that prevent their having a just or decent political and social regime. (Ibid. at 37.) Ibid.

is Ibid. at 3, n. 2. For example, decent nonliberal peoples respect the human rights to life, liberty, property, and formal equality (ibid. at 65), but, obviously, not to equality in political participation, although decent nonliberal societies do respect the right to dissent (ibid. at 61). 
Given the characteristics and fundamental interests of liberal and decent nonliberal peoples, each will accept the principles of the Law of Peoples. ${ }^{19}$

The world contains more than liberal and decent nonliberal peoples, though. ${ }^{20}$ Rawls' construction makes it clear that the Law of Peoples simply does not apply to outlaw states, which are defined as those that fail to respect basic human rights or are governed by rulers who do not attempt to advance the common good. Of course this does not mean that anything goes with respect to outlaw states, but only that the behaviour of members of the Society of Peoples toward outlaw states is regulated by something else (in particular, by prudential judgments regarding what steps are most likely to bring outlaw states into the Society of Peoples). ${ }^{21}$ Peoples living in unfavourable conditions face material conditions that make it exceedingly difficult to "achiev[e] a well-ordered regime."22 Their actions too are not regulated by the Law of Peoples, because their inability to achieve a well-ordered regime makes it unfair to impose on them any of the obligations of the Law of Peoples. Peoples in burdened societies are nonetheless not invisible to the Law of Peoples, because liberal and decent nonliberal peoples have a duty to assist them up to the point where the societies are no longer burdened. ${ }^{23}$ Interestingly, Rawls has almost nothing to say about the place of benevolent absolutisms in the Law of Peoples, other than to note that they have a right to go to war in self-defence because their benevolence means that they honour human rights and are non-aggressive. ${ }^{24}$

Perhaps the most problematic part of the construction is its base, where liberal peoples must tolerate decent nonliberal ones. Rawls argues, persuasively to me, that liberal peoples will accept a principle of toleration applicable to decent nonliberal peoples because the latter respect human rights and are guided by a common-good conception of justice, qualities that entitle them, from the liberals' own perspective, to "a due measure of respect" (ibid. at 61). I address the question of whether the world contains even liberal and decent nonliberal peoples in section IV below.

See supra note 4 at 93 : "Their [i.e., members of the Society of Peoples] long-run aim is to bring all societies eventually to honor the Law of Peoples and to become full members in good standing of the society of well-ordered peoples.... How to bring all societies to this goal is a question of foreign policy; it calls for political wisdom.... These are not matters to which political philosophy has much to add...."

23. Ibid. at 106: "The long-term goal of (relatively) well-ordered societies should be to bring burdened societies, like outlaw states, into the Society of well-ordered Peoples." Rawls devotes a large section to explaining why the duty of assistance does not entail a general principle of distributive justice among members of the Society of Peoples (ibid. at 106-20). He argues against two of his most prominent followers in the academy, Charles Beitz and Thomas Pogge, each of whom argued that the difference principle of $A$ Theory of Justice (Cambridge: Belknap Press of Harvard University Press, 1971) should be applied globally. See: C.R. Beitz, Political Theory and International Relations (Princeton, NJ: Princeton University Press, 1979); T.W. Pogge, "An Egalitarian Law of Peoples" (1994) 23 Philosophy \& Public Affairs 195. My interests in the field lie in areas other than international distributive justice, and so I refrain from commenting on Rawls' argument on these matters.

24 Rawls, ibid. at 92. Rawls' comprehensive index identifies this as the only substantive discussion of benevolent absolutisms, and I found no others myself. 
With this description in hand, I proceed to some critical observations about The Law of Peoples. ${ }^{25}$

\section{The LAW OF PeOples versus COSMOPOLITAN Liberalism}

As Charles Beitz points out, ${ }^{26}$ The Law of Peoples does only part of the job that Rawls did in $A$ Theory of Justice. In that work, Rawls identified some principles of justice and made two kinds of arguments. First, these principles were compatible with the characteristics that Rawls specified that individuals had. Second, these principles were more compatible with those characteristics than a major competitor, utilitarianism. The Law of Peoples identifies principles that are compatible with the characteristics of peoples, but it does not argue in any systematic way that those principles are more compatible with such characteristics than the Law of Peoples' major competitor. ${ }^{27}$ That competitor is cosmopolitan liberalism, according to which the same principles of justice apply to everyone everywhere. So, for example, the Law of Peoples insists that a set of truly basic human rights be protected, but acknowledges that liberal peoples would insist, for themselves, that other rights be protected as well. Decent nonliberal peoples will respect the basic human rights, but need not protect others that liberals think flow from essential human characteristics. Similarly, according to Rawls' analysis in A Theory of Justice, a liberal people will adopt a specific principle of distributive justice, but the Law of Peoples does not insist that the same principle be applied to the distribution of goods among peoples.

The cosmopolitan liberal might be convinced that Rawls's Law of Peoples is compatible with the interests of peoples, but might still wonder whether cosmopolitan liberalism would beat it in competition. The doubts would be founded on the observation that peoples are made up of people, that is, of the individuals whose characteristics are fundamental to liberalism. To a liberal, individuals are entitled to a rich set of human rights, but the Law of Peoples is developed on the assumption that those individuals who happen to live in a decent nonliberal society are entitled to a more impoverished (though not empty) set. How can the aggregation of individuals into a people work such a dramatic change in their liberal entitlements? ${ }^{28}$

I note that Rawls' prose style is unforgiving, though nearly crystal clear. That is, every word is chosen with such great care that readers must be exceedingly attentive. It is quite misleading to read the book to get its general drift, for in doing so one runs a great risk of missing the interconnections among points and, most important, the architectural care with which the argument is constructed. For example, here Rawls provides a precise account of the original position that is, in my view, entirely consistent with his use of the idea in earlier works. Yet, those works generated an enormous critical literature predicated on an understandable misreading by people merely reading to get the drift of the argument.

26. See Beitz, supra note 1.

27 Rawls does assert, and briefly argue, that "the eight principles ... are superior to any others" (supra note 4 at 41 ). He argues that "no people ... is prepared to count ... the benefits for another people as outweighing the hardships imposed on itself" (ibid. at 40), and therefore rejects global utilitarianism as a first principle. already been taken into account in identifying the thicker set of rights that people have. 
Rawls defends his attention to peoples, rather than persons, by an analogy to property. Drawing on standard economic theory, Rawls writes, "the point of the institution of property is that, unless a definite agent is given responsibility for maintaining an asset and bears the loss for not doing so, that asset tends to deteriorate." ${ }^{29}$ For human beings, the relevant asset is the world's resources. ${ }^{30}$ The world's resources will deteriorate and become insufficient to sustain the species unless they are allocated to a responsible agent. Rawls acknowledges that the responsible agent could in principle be a world government, ${ }^{31}$ but rejects that possibility because a world government "would either be a global despotism or else would rule over a fragile empire torn by frequent civil strife as various regions and peoples tried to gain their political freedom and autonomy." ${ }^{\text {"32 }}$

Without a world government, then, the world's resources must be allocated to smaller units; individuals organized to govern the resources located in particular territories. This has two consequences. First, and less important for present purposes, the fact that the world's resources are distributed unevenly among any territorially defined units supports the duties of assistance in the Law of Peoples. ${ }^{33}$ Second, the organization of individuals into territorially defined units creates a new kind of fundamental interest. According to Rawls, individuals have a fundamental interest in self-respect. A people has an analogous interest, for "self-respect of themselves as a people, resting on their common awareness of their trials during their history and of their culture with its accomplishments. ${ }^{34} \mathrm{~A}$ people's history and culture rest on its control over resources located in a territory. ${ }^{35}$ The diversity among individuals, coupled with the sheer fact of historical contingency, raises the possibility that there will be decent nonliberal peoples. That possibility in turn justifies constructing a Law of Peoples that accommodates such peoples' need for self-respect.

This argument certainly goes a fair distance to the end of justifying a Law of Peoples rather than a law of persons. It does not go all the way, however, for two reasons, each of which identifies a dynamic that might make it unnecessary to develop a Law of Peoples different from cosmopolitan liberalism. First, acknowledging that a people organized as self-governing over a territory will develop a fundamental interest in respect for them as a people, I wonder why we should think that such an interest will (always?) prevail over the fundamental interest each one of them has in self-respect as a person. So, for example, it could well be that the interest in self-respect for a people will support only a thin set of fundamental human rights, but the interest in self-respect of each individual in that

Supra note 4 at 39.

Rawls describes the asset as "the people's territory" (ibid.). I think this is elliptical; taking the territory already allocated to a people as standing for the resources of the world located in a territory, the responsibility for which must be allocated to someone.

See $i$ ibid. (using the phrase, "In the absence of a world-state").

lbid. at 36.

I take it to be impossible to draw boundaries in a way that would give each territorially organized people a basket of resources of equal value.

Supra note 4 at 34.

Beitz argues that a people develops a culture either in order to, or as a by-product of its efforts to, organize itself as a political community. A common culture, Beitz argues, provides the motivation to support the people's political institutions (Beitz, supra note 1). 
same people might be strong enough to overcome that interest and support a thicker set of human rights.

Rawls provides his answer to this concern with his definition of a decent consultation hierarchy or, more generally, with his definition of decent nonliberal societies as those whose rulers act in accordance with a common-good conception of justice. ${ }^{36}$ Consider the position of women in traditionalist societies. One can imagine a decent consultation hierarchy, in which women do not have equal rights with men, but where women's representatives present their interests to the rulers. The consultation hierarchy is justified as an institutional expression of the people's fundamental interest in self-respect, coupled with a distinctive history giving rise to the people's commitment to a decent, though nonliberal, common-good idea of justice. As I see it, the consultation hierarchy might generate a thin, nonliberal set of rights if the body representing women might ask for only the thin set because its members (not all of whom must be women) ${ }^{37}$ believe that the thin set respects the people's history better than liberalism's thicker set of rights.

As Rawls points out, "All societies undergo gradual changes, and this is no less true of decent societies than of others." 38 Rawls offers this as an explanation for liberal peoples' willingness to tolerate nonliberal ones that may be able "to reform themselves in their own way." 39 The observation may have more subversive implications than Rawls recognizes. Consider a decent consultation hierarchy operating over time. At the outset, why would the body representing women not ask for the thin set of rights plus one right from the thicker liberal set? The augmented set of rights would be more compatible with the interests of women considered as persons. And, given the malleability of culture, such a modest request would be unlikely to make the slightly augmented set so wildly at variance with the people's history as to deny it its fundamental interest in self-respect. And, after a while, why would the body representing women not ask for another liberal right? This process, extended over time, suggests to me that decent hierarchical societies have an unstable governance structure. ${ }^{40}$ The instability leads to liberalism. But if so, the Law of Peoples, taken as a set of principles to regulate the world in a steady-state with liberal and decent nonliberal peoples, might be unnecessary; cosmopolitan liberalism

Rawls writes that "the legal system of a decent hierarchical people must contain a decent consultation hierarchy" (supra note 4 at 71). Here, I think Rawls errs. All that is needed, I think, is that the rulers of a decent hierarchical society take into account the true interests of all in the society. A consultation hierarchy might be the most effective method of discerning those interests, but I do not see why it must be the only one.

Rawls believes that an appropriate response to the historical subordination of women is to ensure that "a majority of the members of the bodies representing the (previously) oppressed be chosen from among those whose rights have been violated" (ibid. at 75 ). Note, importantly, that the body representing women could have a substantial minority of men; obviously the decision-making body could have a substantial majority of men. lbid. at 61 .

Ibid.

My concern here is empirical, not conceptual. As time passes, a people that accepts new liberal values one by one will not be "the same" people. The incremental process means, though, that such a people will not have sacrificed what is normatively valuable in being a people, such as self-respect, a "common awareness of their trials during their history and of their culture with its accomplishments" (ibid. at 34). 
would regulate a world in which the only subjects of regulation were liberal peoples, or peoples in the process of becoming liberal. ${ }^{41}$

My second concern about Rawls' argument, that the subject of concern is peoples rather than persons, is with his rejection of a world government, and rests (as the previous one did) on the dynamics of the situation. Rawls is concerned that a world government would be despotic or torn by disorder. This, it seems to me, overlooks the possibility of a mild federation in which each people has a substantial degree of "freedom and autonomy," but within broad limits. As time passes and the benefits of federation accrue, the limits can approach those that cosmopolitan liberalism would impose directly. ${ }^{42}$

Perhaps the proper response to these concerns is that they rest on a vision that is too utopian. I do not see why. Like Rawls' realistic utopianism, I have taken people as they are. Indeed, the processes I have sketched rest on a human characteristic that Rawls himself identifies through his insistence that individuals located in self-governing territories will develop distinctive histories and cultures. The characteristic he and I rely on is human malleability - not in the sense that social engineers can consciously design institutions to alter individuals' commitments and preferences, but in the far more modest sense that those commitments and preferences can change in response to the social circumstances in which individuals find themselves.

An alternative response is that the Law of Peoples is not in fact designed for a steadystate world. Instead, it regulates the world as it is, always in transition from one in which there are both liberal and decent nonliberal peoples, to one in which all peoples are liberal. As noted earlier, even a world composed entirely of liberal peoples requires a Law of Peoples, although such a Law might well have more heft than the one Rawls describes. ${ }^{43}$ And yet, if we saw the world as always in transition, I suspect that we would rather heavily discount questions of principle in favour of questions of prudence, and ask our leaders to pursue the course most likely to bring about a peaceful transformation of decent non liberal peoples into liberal ones. ${ }^{44}$ For these reasons, I believe that Rawls has not shown that the Law of Peoples is more compatible with fundamental human interests than is cosmopolitan liberalism.

\section{A "REALISTIC UTOPIA"?}

Rawls asserts that he is constructing a Law of Peoples that is a realistic utopia, realistic because it takes people as they are and utopian because it seeks to develop laws as they

Of course there might be prudential, rather than principled, reasons for liberal states to refrain from actions aimed at accelerating the process of transformation.

I have spelled out this argument in more detail in M.V. Tushnet, "Federalism and Liberalism" (1996) 4 Cardozo J. Int'l and Comp. L. 329.

4. For example, it seems to be reasonably clear that a Law of Peoples designed solely for liberal peoples would contain a thicker set of human rights than the Law of Peoples Rawls describes. As noted above, he specifies the principles of the Law of Peoples as he does to ensure that they could be accepted by decent nonliberal peoples as well as liberal ones.

The thought here is parallel to the one that Rawls articulates with respect to outlaw states and to peoples burdened by unfavourable conditions. 
could be if people pursued their commitments as fully as they could. Pretty clearly, his argument gains rhetorical force by trading on a reader's sense that there really are liberal societies and decent nonliberal hierarchies in the world. Rawls spends a few pages describing a hypothesized decent nonliberal hierarchy that he calls "Kazanistan."4s Modeled on aspects of non-fundamentalist Muslim societies, Kazanistan favours Islam in its political structure by allowing only Muslims to hold high official positions, but it tolerates other religions and does not otherwise discriminate in public life against nonMuslims. Kazanistan seeks to extend Islam by non-coercive means, not by aggressive war. Its governing institutions consult all segments of the society, with the aim of "establish[ing] a decent and rational Muslim people respecting the religious minorities within it."46

Kazanistan is imaginary, but readers are implicitly invited to compare it to real-world societies; present-day Jordan, perhaps, or Egypt. Similarly, but with less argument, readers are invited to imagine that real-world liberal democracies are governed in the way that liberal peoples are to be governed in Rawls's construction.

My concern here is that Rawls may be presenting what might be called an idealized realism. ${ }^{47}$ I doubt that any real-world state has a decent consultative hierarchy and respects fundamental human rights to the degree that Kazanistan does, and I doubt as well that any real-world liberal state is a Rawlsian liberal democracy. We might understand Rawls as offering idealizations. He could be taking the principles to which the people of liberal and decent nonliberal societies say they are committed, and working out the implications of truly acting in accordance with those principles. Real-world societies, he might say, betray their own principles. But a realistic utopian might seek to bring the realworld peoples' actual institutions into alignment with their own animating principles, as a prelude to developing a Law of Peoples.

I wonder whether this understanding is compatible with Rawls' project, however. For one thing, he acknowledges that the decent hierarchical societies he describes are conceptual constructs, not (even) approximations of empirical reality, and he concedes the possibility that only liberal societies can respect even the thinned-down set of fundamental human rights. ${ }^{48}$ For another, there is a tension, I believe, between the view that Rawls is offering an interpretation of existing principles to guide revisions in practice, and his insistence that his construction asks what "you and I, here and now" would "regard ... as

Supra note 4 at $75-78$

Ibid. at 77.

In thinking about Kazanistan and Rawls' idealized liberal democracies, I was reminded of H.I. McDonnough's (Nicholas Cage's) concluding monologue in the film Raising Arizona, a lyrical description of a utopian land where families live in harmony. The monologue's comic twist comes when McDonnough ends by identifying that land: "Utah." (See: J. Coen et al. Raising Arizona, produced by E. Coen and directed by J. Coen, 94 min., Twentieth Century Fox Home Entertainment, 1987.)

4 Rawls writes, "my remarks about a decent hierarchical society are conceptual. I ask, that is, whether we can imagine such a society; and, should it exist, whether we would judge that it should be tolerated politically" (supra note 4 at 75, n. 16); and also "[t]he Law of Peoples assumes ... that decent hierarchical peoples exist, or could exist, and considers why they should be tolerated and accepted by liberal peoples as peoples in good standing" (ibid. at 79). 
fair and reasonable conditions." ${ }^{.49}$ The rhetorical force of this formulation comes from its stress on what you and I would here and now accept, not from the proposition that you and I would, after a suitable period of reflection on our existing commitments, come to accept. I acknowledge that the latter reading is possible, particularly in light of Rawls' occasional use of the word would $;{ }^{50}$ but that reading makes the construction less realistic than Rawls seems to want it to be.

Another version of the concern I have expressed is common among legal academics, though not, I think, among political philosophers. ${ }^{51}$ The reading I have suggested asks us to reflect on our basic commitments and to revise our institutions to bring the commitments and institutions into alignment. At least as I understand related discussions among legal academics, we tend to think that our institutions do indeed reflect our considered understandings of our basic commitments, and someone who sees a disjuncture between commitments and institutions has not fully grasped what our commitments really are. Rawls could of course respond that this observation does not undermine his construction, which rests on the implications that we can draw from a rather restricted set of fundamental human characteristics and commitments. Rawls specifies that set in response to two concerns: that it not be too unrealistic, and that it generate interesting conclusions about political justice and the Law of Peoples. Fair enough, but the first of the concerns supporting Rawls' specification does undermine the claim that he is describing a realistic utopia.

Suppose we really did take people as they are. The Law of Peoples would regulate near-liberal peoples, almost decent quasi-hierarchical nonliberal peoples, and (perhaps) not quite benevolent absolutisms. ${ }^{52}$ I cannot offer the principles of a Law of Peoples of that sort, for two reasons. The less important reason is that, although I understand the structure of Rawls' construction, I am not facile in thinking in the way that Rawls does. ${ }^{53}$ The more important reason reiterates a theme that I have already stated: I strongly suspect that relations among non-idealized peoples will be best regulated according to prudence rather than principle. ${ }^{54}$ If so, as Rawls points out, political philosophers may have little to say

\section{Ibid. at 30.}

One formulation has it that the original position "Imodels what we regard you and I, here and now as fair and reasonable conditions" (ibid.); the next is that the "conception of political justice the parties would select is the conception that you and $\mathrm{l}$, here and now, would regard as reasonable and rational and supported by the best reasons" (ibid.). st I am genuinely uncertain whether, if The latter might be included in the domain of the Law of Peoples because they might not be dramatically different from the quasi-hierarchical nonliberal peoples who are within the domain. In this connection I think it regrettable that Rawls does not devote much attention to describing principles of a Law of Peoples that a benevolent absolutist could accept, because not quite benevolent absolutisms seem to be more prevalent than consultative nonliberal hierarchies.

Rawls deals with what he calls nonideal theory of two sorts: situations in which some regimes "refuse to comply with a reasonable Law of Peoples," and situations in which some peoples find themselves in "unfavourable conditions" (supra note 4 at 5). This is a different sort of non-ideal theory than the one with which I am concerned, dealing as it does with cases in which the idealized peoples (who are the subjects of the Law of Peoples) must deal with other peoples, whereas I am concerned with deviations from the ideal by the subjects of the Law of Peoples themselves. 
about a truly realistic Law of Peoples except insofar as they might be able to specify preconditions for the exercise of statesmanlike prudence (such as the preservation of the territory out of which the statesman operates)..$^{55}$

\title{
V. CONCLUSION
}

Rawls describes this book as "the culmination of [his] reflections on how reasonable citizens and peoples might live together peacefully in a just world." The Law of Peoples forms an appropriate conclusion to Rawls' great trilogy. Cosmopolitan liberals might well conclude, after giving the matter great thought, that Rawls has not demonstrated the superiority of his Law of Peoples over theirs, and citizens of the real world seeking to live together peacefully while advancing toward justice might well conclude, after equally great thought, that they should be more concerned with prudence than with principle. But, as was true of the works that preceded The Law of Peoples in Rawls' trilogy, The Law of Peoples raises questions and suggests answers that those seriously concerned about the normative dimensions of international relations will have to deal with over the next generation.

\author{
Mark Tushnet \\ Carmack Waterhouse Professor \\ of Constitutional Law \\ Georgetown University Law Center
}

Without developing the thought systematically, I suggest that a "law of the preconditions for statesmanship" would have much the same content as a law resting on traditional presumptions about national self-interest. 